\title{
Women Leader and Political Linkage: Case Studies in Kutai Kertanegara and Bolaang Mongondow ${ }^{1}$
}

\section{Devy Dhian Cahyati}

Gadjah Mada University, Yogyakarta

\section{Desiana Rizka Fimmastuti}

Gadjah Mada University, Yogyakarta

\section{Norin Mustika Rahadiri Abheseka}

Gadjah Mada University, Yogyakarta

\section{ABSTRACT}

Strengthening democracy in Indonesia provides an opportunity for women to involve informal politics. This condition is not only to show women's abilities but also to mainstream gender issues in public policy. This article explores cases of Rita Widyasari as Regent in Kutai Kartanegara and Yasti Soepredjo Mokoagow as Regent of Bolaang Mongondow to understand how they build political linkage in a local context. In this research, we use a qualitative method to gather deep information about women leaders and their linkage. The research shows that their success can not be separated from their ability to build and maintain the networks with various actors in the region, such as economic actors, civil society, and political actors. Although Rita and Yasti use the different pattern to build a local network, this research indicates that political linkage becomes one of the important points to establish women political career.

\section{KEYWORDS}

Bolaang Mongondow; Kutai Kertanegara; linkage; political linkage; women leader

\section{Correspondence}

Research Center for Politics and Government (PolGov), Departemen Politik dan Pemerintahan, Fakultas IImu Sosial dan IImu Politik, Universitas Gadjah Mada. JI. Sosio Yustisia No.1, Karang Malang, Caturtunggal, Kec. Depok, Kabupaten Sleman, Daerah Istimewa Yogyakarta 55281.

Email: devy.dhian@gmail.com; desiana.rizka.f@mail.ugm.ac.id; rabheseka@gmail.com 


\section{Introduction}

7 fter the fall of the authoritarian regime of The New Order, women have bigger chances 1 to involve in politics. Nevertheless, the percentage of women local leaders in Indonesia 1 fluctuates each year. For instance, only five women win in the local elections in 2007, 30 women elected in 2015 and 13 women were elected in the local elections in 2017 (Republika, 2017). Actually, this phenomenon shows that democracy opens opportunities for women to get involved in the political sector. However, a rule of democracy can not ensure success for every woman. There are many challenges for women who want to involve in politics, especially when they want to be a leader. The challenges for Indonesian women politicians can be found in differences of socio-cultural, religious, economic and regional backgrounds.

In a patriarchy culture, women are considered to have less capacity as a leader. In addition, women's access to political resources is limited even though there has been a democracy system. The policy of gender quotas has been praised as a good way to promote women into politics, even if it is not able to guarantee the active involvement of women. Therefore, we are interested in understanding how women leader compete in a local election while they have to contend with many challenges. In this research, we intend to explore two women local leaders who successfully won 'political battle', they are Rita Widyasari as the regent of Kutai Kartanegara (Kukar) and Yasti Soepredjo Mokoagow as the regent of Bolaang Mongondow (Bolmong). Their success is inseparable from their ability to use their capital to build a political linkage with various actors.

Political linkage could be interpreted as a link among leaders with their constituents, intermediate actors and civil society. Political leaders can use some instruments to build linkage with various actors, for example, the facilities that have been built by intermediary organizations to aggregate and represent public opinion in the government. However, intermediary actors such as political parties can not be the only actor who provides the linkage; sometimes politicians need to build their own political linkage. Therefore, politicians (include women politicians) require an ability to make use of capital to build a political linkage with various actors, especially to win the electoral competition and become leaders. In this research, we found that political linkage not only interconnected among leaders and their constituents but also with the political actors (such as party politics, bureaucracy), economic actors (such as business actor) and civil society actor (such as social community).

The study of political linkage is important because in the fact there are some difficulties in establishing political with various actors, especially for women in a patriarchy culture. Women require many efforts to manifest their capabilities as a politician. Hence, other interest actors could respect to women and societies give their trust to them as a leader. Furthermore, this study aims to explain how women leaders build their political linkages to support their political career. In addition, this study illustrates how political linkage works in the political career of women leaders. Through this study, we intend to produce lessons for women who want to involve in politics and become leaders, in which women need a good capacity and strong political linkage with various actors. 
To understand the relation between women's leader and political linkage, this study applies qualitative methodology using a case study approach in two districts, Kutai Kartanegara in the province of East Kalimantan and Bolaang Mongondow in the province of North Sulawesi. Using cases in both areas, this study explains the phenomenon of women's political linkage, this study seeks to become comprehensive and varied in describing women's pathway to reaching their political position. These two areas were chosen as the location of this study with the consideration that the heads of the two regions are women, namely Rita Widyasari as the Regent of Kukar and Yasti Soepredjo Mokoagow as the Regent of Bolmong.

Although we explain two local women leaders as the object of the research, we do not intend to discredit other female regional leaders. We select both cases because the result of Rita and Yasti vote during the election is quite significant compared to the result of other women's regional leaders. Instead of comparing Yasti and Rita, this study takes a different perspective by describing them as women who succeed in politics and become leaders through a political linkage with various actors. In a different context, characteristics and socio-cultural environment between both women leader makes it unsuitable for comparison and potentially get results that are not balanced.

We use two methods in the process of data collection about women's political linkage. First, indepth interviews were conducted with several actors, such as businessmen, political party leaders, NGO activists, media activists, academics and bureaucracy. The second method is desk study to collect secondary data using previous literature and news in mass media that correlated with this topic.

\section{Women Leader and The Linkages: An Overview}

Women's participation in the political sector becomes important because it could be a way of mainstreaming "responsive gender" in public policy. Women's positions in executive or legislative could be a fundamental step to aggregate, articulate, and then accommodate their interests. Globally, the women's participation in the national parliamentary was increasing from $15 \%$ in 2002 to $19,8 \%$ in 2012 (National Democratic Institute, 2017). Not only have the sensitivity to gender issues, but the women's engagement can also increase the institution's legitimacy, decrease the corruption, and could stimulate the wider collaboration in various sectors, for example in the conflic resolution (Bauer, 2009; Castillejo, 2016). By this explanation, we know that leadership is interesting to be elaborated from various perspectives.

The discourse of women's leadership is not a new study. The trend of the various articles about women's leadership could be separated into two focus, agency perspective, and structural perspective. From the agency perspective, women's leader almost be placed as the actor that can fulfill the obligation of leader although they faced a lot of dilemmas. Some of the studies show that there was gendered social roles and gendered social expectations that embedded on women leader (Rosenbluth, Kalla, $\&$ Teele, 2015). Gendered social roles could be defined as the consequences of women leader as a political leader and as a member of her family Gendered social expectations can be found as the 
people's mind construction about women. Women's stereotype as a wife or mom can influence public opinion about her works.

The embedded roles and expectations women leader has implicated on various studies such as; the roles and the functions of women leaders in legislative (Bochel \& Bochel, 2018), women leader and decisions making (O'neil \& Domingo, 2016), and women leader's stereotype (Wright, 2011). Furthermore, there is a lot of studies wants to make a wider explanation the obstacle of women leaders such as personal obstacle, work condition, and the negative response from her society (Hill, Miller, Benson, \& Handley, 2016). Some of studies also elaborated women in political parties (Castillejo, 2016), the policy for increasing women participation (Innge \& Kayuni, 2016), the regime orientation and its influence on women position in political sector (Rosen, 1995), women participation in the election and the good condition (Bauer, 2009), and a various struggle movement for women participation in public space (King, Cornwall, \& Dahlinn, 2005).

Based on some of the literature above, the dominant perspective showed women leaders as an object and they faced the personal and structural dynamic situation on their leadership in the political sector. This article wants to discuss women as an actor that can make various ways to build her political building. The writer would be specific on women leader's political linkage, besides of personal factors such as communication skills and personality, accessing the linkage is a crucial thing to build political support as a leader.

The linkage can be affected by the development of social capital that could be optimized by women (Eagly \& Carli, 2007 dalam Hill et al., 2016). On the other side, linkage could be an important capital to strengthen women's bargaining position in a patriarchal political system. In Uttar Pradesh (state in northern India), the majority of women legislators elected in 1952 to 1996 have a political background from her family (Singh \& Pundir, 2002). Meanwhile, based on Dick (2013) the strong background for women leaders is becomes the labor leader in her region. From the explanation above we know that family background, personal intelligence, activism from sensitive issues, and her relation with some interest group, pressure group, and political parties have contributed to make a wider linkage and strengthen her position.

There are a lot of kind definitions of linkage. Generally, Aarts (in PolGov and The Asia Foundation, 2014) defined linkage as various relationships between citizens, social organizations, and political systems. Another definition, political linkage could be interpreted as a link between leaders with their constituents, intermediate actors and society actors so that the policies generated are more responsive. Some people argue that the political linkage must be provided by intermediary organizations as their function to aggregate and represent public opinion to the government. The three intermediary organizations are (1) interest groups and pressure groups; (2) new social movements; and (3) political parties.

The other studies defined linkage as the relation between parliamentary members and voters for the public policy purpose (PolGov and The Asia Foundation, 2014). The studies about political linkage by Lay (2010) had tried to the elaborated political linkage between NGO and parliament. 
Lay (2010) separated the linkage into three various types: individual-based linkage, political party, and issues. Indirectly, the studies of political linkage become important because there are difficulties in establishing political linkage between democratic institutions and the society in the same arena, and different arenas (Lay, 2017: 85).

From several definitions above we know that the majority of existed literature or studies assumed linkage as a "political bridge" between citizen and public policy made by legislative or executive. They did not much elaborate another side of linkages political tools (or capital) for the politician. This article wants to discuss the political linkage as a capital that built and maintained by the leader to strengthen their bargaining position. Drawing on two cases of women leader in Indonesia, this article uses the specific conceptual framework by Kitschelt \& Wilkinson (2007: 7) that discussed political linkage as relationship between politicians and citizens as his/her constituent. This relation could be placed as capital for the politician. Women leaders can use this relationship for various purposes, for example, build and maintain their career.

Furthermore, Kitschelt \& Wilkinson (2007) elaborated on the three types of linkages: clientelistic linkage, programmatic linkage, and charismatic linkage. Clientelistic linkages relation between the politician and her/his citizens with material compensation in order to gain support. Programmatic linkage is relation between politician and his/her constituents with policy programs that give a positive impact on all people. Charismatic linkage is the relation between a politician with his/her constituent because of politician's personal charism. The pattern could have happened in a relationship between a leader with another actor. In this case, we use an analytical framework to examine the woman leader's political linkage by dividing it into three actors: political society, economic society, and civil society.

First, the linkage between women leaders and political society can be analyzed from the leader activity with a political party before and after the election. Although most of the studies confirm that women did not have a good atmosphere in a political party (Castillejo, 2016; Hunt, 2007; Sacchet, 2005), we put more attention on this actor because of their function on the democratic system. A political party can be said as the main linkage to facilitate public representation, called "structural functionalism". It works from an aggregative process up to policy implementation. They have several types of linkage: campaign linkage, participatory linkage, ideological linkage, representative linkage, and policy linkage. The operationalization of various linkages could make a strong connection between leader and society (Dalton, Farrell, \& McAlliste, 2011). As we know the political party is the main actor to provide or facilitate linkage between leaders and the constituent but sometimes the political party fails to perform their function and raises another political society actor who can guarantee the occurrence of the linkage.

Second, the linkage between women leaders and economic society can be seen from various businesses that she used for maintaining or building another network, such as contractors, coal mining corporate, palm oil, etc. Third, the linkage between women leaders and civil society can be elaborated from her relation with civil society organizations or communities. Although women have a strong capability for communication (Hill et al., 2016), they faced a big problem because of gender 
stereotypes. Women in Belgia could not easily build a network in a community that did not have a woman member. So they can not easily contact her voters (Rosenbluth et al., 2015). In another line, Sacchet (2005) argue that woman can build alienation with mass media or journalist that have an interest in gender issues. In this way, women could easily communicate her idea to the society.

\section{The Women's Leaders: Background and Context}

Kukar is one of the autonomous regions in Indonesia after the fall of the New Order regime. Previously, Kukar was a part of the Kutai district with various ethnic groups such as Dayak as the majority, Bugis, Java, Madura, Banjar, and so on. Kukar is a wealthy region with various natural resources, such as oil palm, coal, and petroleum. Syaukani Hasan Rais (well known as Kaning) is the first local leader in this region. Before serving as a bupati, Syaukani had a career in bureaucracy and served as chairman of the Kutai House of Representative (DPRD) from 1997 to 1999. Syaukani is known as a charismatic and popular figure because he always makes a close engagement with his society through visited in villages and "blusukan" (Santoso, Bayo, Lopo, \& Sudirman, 2018). Blusukan is an activity to visit some areas to know the condition directly. He officiated as regent in periods 1999-2004 and 2005-2010. However, Syaukani was arrested by the Anti-Corruption Commission (KPK) in 2006 for the corruption of balance fund, land procurement for the construction of Loa Kulu Airport, and social assistance budget (Kompas, 2008).

Rita Widyasari, Syaukani's daughter, following her father for a career in the political sector. Before her engagement in politics, Rita was active in organizations such as youth organizations, social organizations and women's organizations. Rita started her carrier as vice secretary of Golkar from 2005 to 2009. Like her father, Rita used Golkar to get a political position at the local level. Furthermore, Rita was elected as head of legislative in Kukar in 2009 to 2014 period. She is the first woman in Kutai Kartanegara who officiated the position. At the beginning of the period, Rita resigned from her position as head of legislative after elected as bupati in the local election in 2010. Actually, her success can not be separated from the role of team 11 who tried to maintain Syaukani's power.

In the first period, Rita had a development program which is called Gerbang Raja (Gerakan Pembangunan Rakyat Sejahtera/ Development and Welfare Program) as Syaukani's continuation program "Gerbang Dayaku”. Gerbang Raja consists of the implementation of good governance in education, economic, health care services, women empowerment, and infrastructure development. The purpose of "Gerbang Raja" is to reach out to the people of Kukar who are advanced, independent, and prosperous. Rita's policy is considered an innovative policy; therefore she gets some awards from the central government. Moreover, Rita has a close engagement with her people, through "blusukan".

In the 2015 election, Rita proposed as bupati of Kukar along with Edi Darmansyah. They used an independent way and got the highest votes in the local election. After the election, Rita continues the program "Gerbang Raja" which is considered to have been successful in advancing the prosperity of 
Kukar. However, before Rita has finished implementing this program, she has been arrested by KPK because of gratification and bribery from the palm oil company.

Another case happened in Bolmong, this region is an old region in North Sulawesi. The ethnic majority in the region is Mongondow ethnic, and most of the people are Moslems. The dynamic of women politicians in this area is very interesting; women have the ability and opportunity to occupy a political position. Marlina Moha Siahaan was the first woman leader in Bolmong and has the power to influence politics in North Sulawesi. The second woman leader in Bolmong is Yasti Soepredjo Mokoagow, who elected in the local election in 2017.

Similarly Rita Widyasari, Yasti Mokoagow started her political career at the local level by serving as treasurer in PAN. Before active in politics, Yasti was an entrepreneur in North Sulawesi. Yasti is a descendant of Mongondow-Java; his mother came from Dumoga Raya, while his father came from Java. In contrast with Rita, Yasti is not from a politician's family, but her mother was aristocratic in Dumoga. While studying at the Faculty of Social and Political Sciences at Samratulangi University, Yasti joined the student organization, such as the Islamic Students Association (Himpunan Mahasiswa Islam/HMI). After finished her college, she started her career as an entrepreneur by officiated strategic positions in several companies.

Yasti started her political position as a member of the House of Representatives in the period 2009-2014. She received 48.567 votes for North Sulawesi. In the House of Representatives, she is in commission $\mathrm{V}$ in charge of transportation, telecommunications, public works, public housing, rural development, and lagging areas. Then in 2010, Yasti became chairman of the V commission to replace Taufik Kurniawan who served as deputy chairman of the House of Representatives. Meanwhile, Yasti also served as Deputy Treasurer of the Central Executive Board (DPP) PAN from 2010 to 2014. In the 2014 election, Yasti was elected again as a member of the House of Representatives to represent the province of North Sulawesi with 103.801 votes. In this second period, Yasti became a member of the $\mathrm{X}$ commission in charge of education, culture, tourism, creative economy, youth, sports, and libraries. Her political office at the national level ended when she stepped down and then ran for Bolmong.

Yasti participated in the election along with his deputy, Yanni Ronny Tuuk. The couple was promoted by the Indonesian Democratic Party of Struggle (PDI-P), the National Mandate Party (PAN), Prosperous Justice Party (PKS), National Democrat (Nasdem) and National Awakening Party (PKB), while their opponents, Salihi B. Mokodongan and Jefri Tumelap is supported by Golkar Party, Gerindra and Demokrat Party. Yasti-Yanni won elections with 64,86\% votes, while Salihi-Jefri earned $35,14 \%$ of the votes.

There are several visions and missions of Yasti and Yanni. First, to realize clean government through a merit system, e-government implementation, and improvement of public service. Second, economic development through capacity building of small and medium entrepreneurs; increase promotion and investment cooperation; development of regional and village-owned enterprises. Third, infrastructure development for land, sea and air transportation. Fourth, education development. And 
fifth, health improvement through the improvement of infrastructure and access to health services. This mission vision became one of the factors that led Yasti to get support from 4000 volunteers and support from 202 villages. Therefore, after being elected as the Bupati, Yasti is committed to immediately implementing the vision of the mission that has been promised during the campaign.

\section{How to Build The Political Linkage}

Women leaders require linkage to support them in the local elections. The local election is an interesting context because women can be involved not only as voters but also as a candidate. Women have to face a complex situation because the patriarchy culture seems to be a dominant factor, particularly when we discuss a women leader. Political linkage could be placed as a support system and has a crucial role for the elected women leader, including in the case of Rita Widyasari and Yasti Soepredjo Mokoagow.

In the context of representational democracy, the political linkage is not limited to the political parties. Political parties attempt to be the actor who provokes a linkage, but they can not be entirely successful; therefore, the vacant gap was left by the political parties began to be filled by other actors such as interest groups or pressure groups (Lawson \& Merkl, 1988). In this paper, we attempt to categorize the linkage among women leaders and another actor that divided into three actors: political actor, economic actor, and civil society actors.

\section{a. Linkage between Women's Leader and Political Society}

In the process becoming A Regent of Kukar and Bolmong, Rita Widyasari and Yasti Soepredjo Mokoagow used the linkage that they built with various political actors, such as state, political party, and bureaucracy in local or national level. This part begins with a story of Rita Widyasari as the first Women's Regent in Kukar after regional autonomy. Rita Widyasari won the local elections in with vote result 55\% in 2010 using the Functional Groups Party (Golkar) as her political machine. The proximity of Rita Widyasari with Golkar has built since the beginning of her professional political career as Deputy Secretary of the Golkar Party Kukar in 2005-2009 and in 2016 when she was a Head of DPD of Golkar. This phenomenon can not be denied that her winning as a regent made her position in Golkar is quite respected, particularly when she interacted with internal or external people in her organization. She leads the party using a kinship relation, therefore makes people give respect for her.

In the second period, Rita Widyasari took a different pathway to contend in the local elections. She became an independent candidate in local election 2015 in the middle of her position as chairman of Golkar DPD East Kalimantan. Her decision is based on consideration of the Golkar Party condition that has a conflict of dualism management at the central level. Rita realized if used Golkar as her political machine in the 2016 election would threaten the result of her vote because of the internal conflict. Although using an independent way, Rita was able to attract several parties to support her, such as Democrat Party (PD), Prosperous Justice Party (PKS), National Mandate Party (PAN), 
Great Indonesia Movement Party (Gerindra), People's Conscience Party (Hanura). In the election in 2015, Rita won and got an $89 \%$ vote in 2015 . The most interesting in that time was Rita and her vice became the one and only candidate who passed the administrative verification of the Kukar Regional Electoral Commission (KPUD). Previously, there were three candidates who register to join the election, however, two candidates were disqualified because of problems of administrative requirements such as a certificate from their support party (Golkar). At that time, the KPUD was forced to re-open the registration of candidates for the regent.

The relationship between Rita and Golkar is mutually beneficial. On one side, Rita needs Golkar as a place to develop her political career. On the other hand, Golkar also needs Rita as a potential cadre because Rita has charisma and capitals. When Rita decided to be an independent candidate without Golkar as support parties, she reached a significant vote. At that time, Golkar did not give a certificate to another candidate. As a result, the election in Kukar could not be held because Rita was the only candidate who passed the administrative verification. On the other hand, Golkar can not be a winner party without Rita; because from a social perspective, Rita has good capital as a leader. According to Kitschelt \& Wilkinson (2007) argument, the linkage between Rita and political party especially Golkar can be categorized as a clientelistic linkage. Not only with the political party, but Rita also built the same linkage pattern with other politicians and bureaucracy. Rita facilitated people who want to involve as party cadres or run for regional heads, although they are from the same party (Golkar). Indirectly, Rita created a dependence relation to other cadres who get her and established a pattern of patronage.

Rita also made an approach with the Local Device Working Unit (SKPD) in Kukar after officiated as a regent in the first period. Rita admitted that she tried to establish good communication with her staff. She also put forward a non-formal communication style, unlike the bureaucratic communication style in general. In that way, a close engagement makes the coordination between SKPD with the regent goes better than before (Pramita, 2017).

Her charisma and capital owned by Rita closely related to her father, Syaukani. Syaukani was an important figure in Kukar who built his regime and controlled elements of bureaucracy, political parties until the DPRD successfully (Santoso et al., 2018). Syaukani's charisma became a benefit for Rita as his daughter. Previously, some parties had hesitation in Rita; however, the charisma of Syaukani in Kukar succeeded to convince the people, parties and related stakeholders that Rita was able to continue his "relay baton" to be a leader in Kukar. It can be seen in the first period Rita only got a 55\% vote, but in the second period, she had almost $90 \%$ vote. In this case, we can perceive that Rita built a charismatic linkage in Kukar. Regarding this phenomenon, the pattern of the relationship between a politician and her constituents is built on the personal charisma of the candidate (Kitschelt \& Wilkinson, 2007).

If Rita built her political career from the local level, Yasti Soepredjo Mokoagow started her political career as the national political elite. She supported local actors as a strategy to build her linkage, 
which is a political investment for her political career in Bolmong. Starting as a chairman of PAN Bolmong, Yasti was a person who trusted by Hatta Rajasa (Chairman of PAN) and occupied several strategic positions in the party. At the end of 2016, Yasti officially resigned from the Indonesia House of Representatives (DPR RI) and nominated as a Regent of Bolmong. The strong linkage at the actors in local and national that she built while in national level doesn't make Yasti satisfied. She realized that her background as an entrepreneur is not strong enough to guarantee her political career. Therefore, Yasti built a linkage with several local political actors, such as political parties. As a senior cadre of PAN, Yasti persuaded several parties such as the Indonesian Democratic Party of Struggle (PDI-P) as dominated political machine di Bolaang Mongondow(Kumayas \& Sumolang, 2015), PKS, National Democrat (Nasdem) and National Awakening Party (PKB) to support her in the local election. She used a personal approach to party elites to get support when she was a candidate in the election.

Yasti not only established a linkage with political parties but also with bureaucrats. Bureaucrats are the main machine that determines her successes before becoming a leader and after becoming a leader. Moreover, Yasti has more control over the bureaucracy, bigger than Salihi. Yasti has the power to eliminate some bureaucracies in sub-district who are disobedient to her and mobilizes village bureaucrats to involve in the direct campaign to the community, through the door to door method or social celebrations like the wedding party (Kumayas \& Sumolang, 2015).

Actually, Yasti already had some political investment before her nomination as regional head of Bolmong. First, she became a donor for other candidates who want to compete in local/provincial/ district elections. For example, Yasti became a financial and political supporter of Salihi's victory in the 2012 regent elections, so she was basically a patron for Salihi. Therefore, in the local election 2017, Mohamad Wongso required Salihi to return receivables of 6 billion that was used as political expenses in the 2011 election. However, the public suspected that the money belongs to Yasti (Kotamobagu Post, 2016). In addition, Yasti also gives her support for candidates from other regional heads, such as local leader from South Bolmong. This pattern almost like in Rita cases. Second, Yasti has established a closeness with the Governor of North Sulawesi, Olly Dondokambey. Olly and Yasti had close engagement since they were in the national political stage as members of the DPR RI represent North Sulawesi. At the same time, Yasti and Olly became general treasurers in their party (PAN and PDI-P). Hence, Yasti has a quite closeness to some PDI-P elites. Third, Yasti selected the right partner, Yanni Tuuk. Yanni was the Vice Regent of Bolmong in the previous period and has good power in the economy.

As discussed in the previous part, Yasti used political linkage with bureaucracy rather than the political party as a main political machine to win the local election. Her charisma as a party elite at the national-level supportsher to interact with party elite figure from another party. Accordingly, she used a personal approach rather than the institutional approach to build her political linkage.

The political linkage among the candidate and political parties, bureaucracy, and other political actors become a capital for the candidate to win the election. From the explanation above, we found 
that women leaders need a political party as a machine to win the election. Therefore, to get support from the political party, she needs to be a party cadre or coalition with the majority party in the area like Rita Widyasari, or encloses with some party elite like Yasti. Women leaders also used linkage with formal bureaucracy and politicians as a political machine in the election. Using personal capital such as self-charisma is advantages for women in politics.

\section{b. Linkage between Women's Leader and Economic Society}

As mentioned above, linkage with various actors can give support for a politician, one of them is with the economic society such as business groups. Women leaders built political linkage with business groups as an important strategy to gain political support. Both of the women leaders in this article have a different character of linkage. Yasti made her linkage by active in entrepreneurship. She built her own business after she finished college. Meanwhile, the linkage between Rita and the company made her father, Syaukani. This different kind of political linkage of Yasti and Rita would be discussed on this part.

The linkage of women leaders with economic society can not be separated from the local context. As one of the regions in Indonesia with a lot of resources such as coal, oils and palm oil, Kukar made a lot of investors' interest to invest their capital in there. Rita used these opportunities to build strong relationship with coal mining companies, as did his father, Syaukani. Syaukanihas built his career since the New Order era with Golkar as a central role party because of their dominant quantity in local parliaments. His position as the chairman of APKASI (Association of Regencies in Indonesia) also has contributed to his strong and legitimate political position. Under his era, the mining sector was optimized for local revenue. From 2001 to 2006, there was a rocketed increase of mining licenses (Evaquarta, 2008).

Syaukani had a strong interest to maintain his power, not only in his regency but also in his province. He built political investment in various ways, such as making a good relationship with another political party, make a regeneration with 'HMI (Association of Islamic Student ) connection', and put his people in strategic positions. His powerful political linkage was used by his daughter, Rita, to continue his power in Kukar. Rita play a role as the next leader of the political dynasty. She has ever been as a vice-chairman of the Association of Indonesian Construction (Gapensi) Kukar in 2004 - 2007 (Republika, 2017), and she is the chief commissioner of PT. Ketopong Damai Persada (Oranyenews.com, 2017).

Not just rely on her father connections, Rita also established relationships with team 11 . Team 11 has full access to both bureaucracy and the corporation to build her political career. Almost all of the member comes from the Association of HMI and also a member of Golkar. They are Syaukani's cadre and they have a strong loyalty with him because of Syaukani give them some political position. One of the members is Abdul Rasid. He has a media and a license on coal exploration. Her dad's background was being the most powerful factor for her political building. The cadre felt that they 
have an obligation to keep Syaukani's power through Rita. So they initiated a team and offering to help her in various fields.

Rita and her team played a central role in the economic sector. It was a part of the political linkage, specifically clientelistic linkage. Kitschelt \& Wilkinson (2007) defined clientelistic linkage as a relation between the politician and her citizens with material compensation. It can be seen that there was a lot of mining license given on her period to the owner of the corporate from Jakarta, Golkar, KNPI (National Committee of Indonesian Youth), some artists, and also some official functionaries. She gave the license as a gift for the funding support. At the same time, the corporate had to access one of the member team 11 to get the license in an easy way because another way is not easy and high cost, and high risk because it could not be processed. The procedural process looks easy when the corporate has to pay 1 billion, 2 billion for each hectare area. ${ }^{2}$ By this mechanism, she got some portion from the corporate, and also got some support from them. For example, Rita got a lot of shirts from coal mining corporate for her campaign. ${ }^{3}$

From the description above, Rita and her team have a powerful position in resource governance. They have an easy to decide procedural license, but on the other hand, there was some dilemma on overland function. There was a lot of 'mining holes' because of reclamation process did not work well, depends on the corporate. Although there was some protest from the environmental activists, Rita and her team could fix it in various ways. One of the strategies was the politicization of the neighborhood leader (Rukun Tetangga/ RT) and the massive work of Rita's success team. They did not give an easy procedure for activist when someone wants to get citizen identity card (KTP). They got some gifts such as motorcycle, child's scholarship, or a house for their family. ${ }^{4}$

In the other case, Yasti as a woman leader also has its own economic linkage to support her political carrier. Yasti's economic-political linkage is built by laddering a long process. Her carrier as a businesswoman in the field of construction started after she graduated from college. Her strategic position as treasurer of PAN has been a significant factor to make wider linkage for her business. Moreover, her business was growing when she was a officiates Chairman of Commission V DPR RI in charge of transportation, telecommunications, public works, public housing, rural development, and lagging areas.

The same pattern of clientelistic linkage works in this case. Yasti's position in the national parliamentary has contributed to wider access for the contractor to get some projects in the local. The contractors have their own interest in Yasti's linkage to access infrastructural projects as a need for Bolaang Mongondow in the future. At the same time, she maintains her economic linkage by giving financial support for the candidate in Bolaang Mongondow and North Sulawesi local election. By this pattern, the successes candidates who have 'political debt' with Yasti, give an easy way for them to open investation in their area.

Based on these explanations, we can say that her linkage with corporate and politician successfully worked. She successfully maintained the contractor's loyalties with giving access to explore resource 
and as a reciprocity, they gave financial support for Yasti when she was running as a regent candidate in 2017. They easily influenced because of the powerful network and "the kindness" of Yasti's.

The other Yasti's economic linkage built by developed a corporation with palm oil companies. The corporation started 5 years ago, and there were 9 corporates in Santambola. The local society faced several environmental problems such as land used and the impact on sustainability environment (AMDAL). One of the environmental problems came from the cement company. She decided to close the company and continue to build an airport because of her good relationship with the air company. By those mechanisms, Yasti could be a powerful actor in Bolmong. She can build and maintain her own linkage and got a lot of advantages for her political career.

\section{c. Linkage between Women's Leader and Civil Society}

For gaining political support in the elections, women leaders established linkage with civil society. Both Rita and Yasti, are prominent female leaders who are active in youth organizations such as KNPI and HMI. Before active in politics, Rita built the linkage through various social organizations. She officiated as a leader of the Indonesian National Youth Committee (KNPI) from 2005 to 2008. The decision for joined KNPI became an important capital to establish a relationship with youth in Kutai Kartanegara. In addition, to gain for the youth political support, the position as a leader of KNPI could be a way for Rita to expand her political network in local and national level. Her involvement in social organizations, such as in religious, art, social, sports, disability, youth and education, also greatly contributed to Rita's political journey. Furthermore, Rita had a close interaction with the women community by engaged in women's activities and organizations, such as The Family Welfare Development Organization (Pembinaan Kesejahteraan Keluarga/ PKK). Therefore, it can be said that Rita has made the political investment through built a linkage with civil society groups.

The linkage that has been established among Rita and the social organizations continued until she was elected as regent of Kutai Kartanegara in the first period. Rita preserves her constituents through some popular programs. In the education sector, she made several popular policies such as English language program development for teachers in collaboration with the University of Cambridge. In the economic sector, Rita created an economic empowerment program for women, especially in rural areas. In the social sector, she has a home surgery program for people in the village. Moreover, Rita contributed to reviving the art of culture in Kutai Kartanegara, such as reviving the Erau festival and performed some rock music. The implemented programs have made Rita known as a popular and innovative regional leader. Several awards and social positions were attributed to the first female district head in East Kalimantan. With this popularity, Rita won elections and served as the Bupati of Kutai Kartanegara for the second period.

Meanwhile, Yasti Mokoagow built a linkage with civil society when she joined in HMI. Through this organization, she gained support networks, including when she proposed for the regent of Bolaang Mongondow. Compared with Rita, Yasti's closeness to civil society is less powerful. Yasti 
is better known as a businessman and politician with a career at the national level. The linkage that built among Yasti and civil societies was not forceful, so it gives little chance for Yasti to win a local election. However, Yasti executed vote-buying through the bureaucratic machine in local election 2017; and the process was accepted by the public, without getting entangled with legal issues or election violations (Sumampouw, 2018).

In addition to social organization, women leaders built linkage with mass media at the local level. Relation with mass media has been built during the election period. However, the mass media has an important role in shaping public opinion of the regent candidates in society. The linkage among politicians and the mass media is needed to support the success of politicians to win the election. Furthermore, the linkage between women leader and mass media is important to support programs which are being carried by women leader.

Our research discovers that both Rita and Yasti maintained their linkage with the mass media to support the election and their programs after the election. Similar to her dad, Rita is well known for giving "envelopes" to journalists in Kutai Kartanegara. The linkage formed between Rita and the mass media is more clientelistic. Clientelistic linkage is a pattern of relationship between a politician with material gains for the citizens that would provide support to him (PolGov and The Asia Foundation, 2014). Rita needs reporters to make news with a positive image, while journalists need more money from Rita as their additional income. Yasti Mokoagow also relies on mass media to establish a positive image during and after the election. During the elections of Bolaang Mongondow in 2017, Yasti had a successful team from a journalist background. Moreover, there are some local media owners who give their support to Yasti. Some of them are the Manado Post Director (part of the national media group of Java Post), who have been a friend with Yasti, and Totabuan News that owned by the politician in DPRD Bolaang Mongondow, Yusra Alhabsyi.

On the whole, we argue that the linkage that builds up among women leaders and civil societies is more characteristic of clientelistic. The provision of material benefits, whether in the form of cash money or development assistance, is a key to establish a relationship between the two actors. Both Yasti Mokoagow and Rita Widyasari used the money to get support in the elections. The linkage is also undertaken by the provision of programs to constituents, which support women leaders during the local election, as did Rita Widyasari.

\section{Conclusion}

Democratization in Indonesia, especially the post-New Order can give a wider opportunity for women in the political sector, not only as a voter but also as a candidate. This research shows women leaders in local politics have built a political linkage as their capital to win the local election. Cases of Yasti in Bolaang Mongondow and Rita in Kutai Kartanegara illustrate that women leaders use their linkage to establish a political support system from other actors, such as economic actors, civil society, and political actors. 
Yasti Mokoagow is one of strong women leader that built the linkage by herself. The linkage that she built can be seen from her bureaucratic networks, entrepreneurs, politicians in North Sulawesi, mass media, and civil society organizations. Meanwhile, Rita has a different condition, in which she maintained her father's network. Based on this research, we argue that political linkage is one of the important things for women who want to strengthen their political careers. The pattern of linkage that is built by both of women leaders tends to clientelistic linkage through material exchange with another actor.

\section{Acknowledgment}

Thanks to the Power, Welfare and Democracy research team in Kutai Kartanegara (2016), led by Purwo Santoso, Willy Purna Samadhi, Debbie Prabawati, Ernawati and Sudirman on 8-13 February 2016. As well as the Local Election Project research team in Bollaang Mongondow (2017), led by Abdul Gaffar Karim, Longgina Novadona Bayo, and Alan Griha Y.

\section{Funding}

The research of this article was from 2 different collaborative projects between Faculty of Social and Political Sciences, Gadjah Mada University, Yogyakarta and University of Oslo, Norway in the Power, Welfare and Democracy project. Also between the Faculty of Social and Political Sciences, Gadjah Mada University and the Australian National University (ANU) Australia in Local Election project.

\section{Notes}

1 This paper has been presented at "Women's Leadership and Democratisation in the 21st Century Asia" in International Conference and Workshop on Gender that organized by Research Center for Politics, LIPI, held in Jakarta, 27-28 April 2018.

2 Interview with Herdiansyah Hamzah (interviewed by Purwo Santoso, February 12, 2016).

3 Interview with Aqmal Rabbany, Didit Haryadi, Pius Erick Nyompe (interviewed by Purwo Santoso, February 10, 2016).

4 Interview with Aqmal Rabbany, Didit Haryadi, Pius Erick Nyompe (interviewer Purwo Santoso, February 10, 2016).

\section{References}

Bauer, J. (2009). Women and the 2005 Election in Liberia. The Journal of Modern African Studies, 47(2), 193-211. https://doi.org/10.1017/S0022278X09003802

Bochel, C., \& Bochel, H. (2018). Women 'Leaders' in Local Government in the UK. Parliamentary Affairs, 61(3), 426-441. https://doi.org/doi.org/10.1093/pa/gsn010 
Castillejo, C. (2016). Women Political Leaders and Peacebuilding. Retrieved from https://ethz.ch/ content/dam/ethz/special-interest/gess/cis/center-for-securities-studies/resources/docs/6ccaf3 f24b120b8004f0db2a767a9dc2.pdf

Dalton, R. J., Farrell, D. M., \& McAlliste, I. (2011). Political Parties and Democratic Linkage: How Parties Organize Democracy. Oxford: Oxford Scholarship.

Dick, W. (2013). "Vigorous-Minded and Independent": Ellen Mulcahy as a Labour Leader. Liverpool University Press, (104), 31-48. https://doi.org/10.5263/labourhistory.104.0031

Evaquarta, R. (2008). Bussiness and Political Actor Relationship In Indonesia Local Autonomy Project: A Comparative Study on Batam and Kutai Kartanegara Regency. In The 17th Biennial Conference of the Asia Studies of Australia. Melbourne: Australia Political Science Association (APSA).

Hill, C., Miller, K., Benson, K., \& Handley, G. (2016). Barriers and Bias: The Status of Women in Leadership. Washington. Retrieved from https://files.eric.ed.gov/fulltext/ED585546.pdf

Hunt, S. (2007). Let Women Rule. Foreign Affairs, 86(3), 109-120. Retrieved from https://www.jstor. org/stable/20032353

Innge, A., \& Kayuni, H. (2016). Women in Politics in Malawi. Bergen and Zomba: Chr. Michelsen Institute (CMI), Department of Political and Admininstrative Studies (PAS).

King, B. G., Cornwall, M., \& Dahllinn, E. C. (2005). Winning Woman Suffrage One Step at a Time: Social Movements and the Logic of the Legislative Process. Social Forces, 83(3), 1211-1234. https://doi.org/10.1353/sof.2005.0037

Kitschelt, H., \& Wilkinson, S. I. (2007). Citizen-politician linkages: an introduction. In H. Kitschelt \& S. I. Wilkinson (Eds.), Patrons, Clients, and Policies (pp. 1-49). Cambridge: Cambridge University Press. https://doi.org/10.1017/CBO9780511585869.001

Kompas. (2008). MA Vonis Syaukani Enam Tahun. Retrieved March 3, 2018, from https://nasional. kompas.com/read/2008/07/29/00512211/ma.vonis.syaukani.enam.tahun

Kotamobagu Post. (2016). Yasti Vs Salihi? Dibalik Drama Piutang Rp6 Miliar (Bagian I). Retrieved March 2, 2018, from http://kotamobagupost.com/bolmong/yasti-vs-salihi-dibalik-dramapiutang-rp6-miliar-bagian-i/

Kumayas, N., \& Sumolang, S. (2015). Perilaku Pemilih dalam Pemilihan Umum Di Kabupaten Bolaang Mongondow. Bolaang Mongondow: Komisi Pemilihan Umum Kabupaten Bolaang Mongondow. Retrieved from https://dokumen.tips/documents/perilaku-pemilih-dalam-pemilu.html

Lawson, K., \& Merkl, P. H. (1988). When Parties Fail Emerging Alternative Organizations. Princeton: Princeton University. Retrieved from https://www.jstor.org/stable/j.ctt7ztg1n

Lay, C. (2010). Broken Linkages: A Preliminary Study on Parliament-CSOs Linkages in Indonesia. In The Panel on Indonesian Democracy in Comparative Perspectives at Euroseas Conference. Guttenberg.

Lay, C. (2017). Tautan Politik antara Pengrajin Batik, Parlemen, dan Masyarakat Sipil di Yogyakarta. Prisma Jurnal, 36(1), 83-99. 
National Democratic Institute. (2017). Handout: Why Women In Politics? Washington: National Democratic Institute. Retrieved from https://www.ndi.org/sites/default/files/Handout 4 - Why Women in Politics.doc

O'neil, T., \& Domingo, P. (2016). Women and Power: Overcoming Barriers to Leadership and Influence. London: Overseas Development Institute.

Oranyenews.com. (2017). Profil: Rita Widyasari, Penerus Dinasti Syaukani di Kutai Kartanegara. Retrieved March 10, 2018, from https://www.oranyenews.com/2017/09/2803/profil-ritawidyasari-penerus-dinasti-syaukani-di-kutai-kertanegara/

PolGov and The Asia Foundation. (2014). Executive Summary Survey Perilaku Pemilih dan Linkage Politik. Yogyakarta: JPP \& TAF. Retrieved from https://polgov.fisipol.ugm.ac.id/f/145/2014laporan-eksekutif-summary-perilaku-pemilih-pemilu-penguatan-political-linkage-1910.pdf

Pramita, E. (2017). Rita Widyasari dan Rahasia Memajukan Kutai Kartanegara. Retrieved March 10, 2018, from https://majalahkartini.co.id/berita/rita-widyasari-dan-rahasia-memajukan-kutaikartanegara/

Republika. (2017). 13 Perempuan Terpilih di Pilkada 2017, Siapa Saja? Retrieved December 8, 2018, from https://nasional.republika.co.id/berita/nasional/pilkada/17/02/22/olr0oz382-13perempuan-terpilih-di-pilkada-2017-siapa-saja

Rosen, S. (1995). Women and Political Participation in China. Pacific Affairs, 68(3), 315-341. https:// doi.org/10.2307/2761128

Rosenbluth, F., Kalla, J., \& Teele, D. (2015). The Female Political Career. The World Bank and Women in Parliament. Retrieved from https://www.womeninparliaments.org/wp-content/uploads/2015/01/ Final_13012015_The-Female-Political-Career.pdf

Sacchet, T. (2005). Political Parties: When do they work for Women? Retrieved from http://citeseerx. ist.psu.edu/viewdoc/download?doi=10.1.1.553.8711\&rep=rep1\&type=pdf

Santoso, P., Bayo, L. N., Lopo, Y. H. L., \& Sudirman. (2018). Kecerdikan Rezim Lokal Menyikapi Konsentrasi Uang: Transformasi Paternalisme Menjadi Oligarki. In P. Santoso, L. N. Bayo, \& W. P. Samadhi (Eds.), Rezim Lokal di Indonesia Memaknai Ulang Demokrasi Kita. Yogyakarta: Yayasan Obor Indonesia.

Singh, P., \& Pundir, J. K. (2002). Women Legislators in UP: Background, Emergence and Role. Economic and Political Weekly, 37(10), 923-928. Retrieved from https://www.jstor.org/ stable/4411837?seq=1\#page_scan_tab_contents

Sumampouw, S. A. (2018). The Money that Never Sleeps: Bureaucratic Movement and Vote Buying Dynamics in Bolaang Mongondow, North Sulawesi. Power Conflict Democracy, 6(1). https://doi. org/10.22146/pcd.31824

Wright, P. (2011). Women and Leadership Style. Gender in Group Psychotherapy, 35(3), 247-253. Retrieved from https://www.jstor.org/stable/41719326 


\section{Informants List}

Aqmal Rabbany, Didit Haryadi, and Pius Erick Nyompe, interviewed by Purwo Santoso, February $10,2016$.

Herdiansyah Hamzah, interviewed by Purwo Santoso, February 12, 2016.

\section{About Authors}

Devy Dhian Cahyati is a researcher at the Research Center for Politics and Government (PolGov), Gadjah Mada University, with the research area around conflict studies and agrarian politics.

Desiana Rizka Fimmastuti a researcher at the Research Center for Politics and Government (PolGov), Gadjah Mada University, with the research area around local politics and youth politics.

Norin Mustika Rahadiri Abheseka a researcher at the Research Center for Politics and Government (PolGov), Gadjah Mada University, with the research area around political gender and election studies. 